\title{
Neonatal sepsis due to glycopeptide resistant Enterococcus faecium from colonized maternal gut- rare case evidence
}

Supram Hosuru Subramanya ${ }^{1 *}$ D, Rajesh Amberpet ${ }^{2,3}$, Dinesh Chaudhary ${ }^{1}$, Niranjan Nayak1, Shashiraja Padukone ${ }^{2,3}$, Indira Bairy ${ }^{2}$ and Shishir Gokhale ${ }^{1}$

\begin{abstract}
Background: Vancomycin-resistant enterococcal infections in the neonatal ICU are growing global problems. We report a case of neonatal septicemia by multidrug-resistant vancomycin-resistant Enterococcus faecium (VRE), the source of infection being the mother's gut.

Case presentation: A newborn male child admitted to the neonatal intensive care unit (NICU) was diagnosed to have mild meconium aspiration syndrome, early onset neonatal septicemia, and bacteremia by multidrug and vancomycin-resistant Enterococcus faecium. Screening of gut flora of the baby and the mother were carried out to trace the source of infection. Stool cultures of the mother and the baby yielded Vancomycin-Resistant Enterococcus faecium. All three isolates of Enterococcus faecium had similar antibiogram, harbored the vanA gene and similar pulsed-field gel electrophoresis pattern. Baby responded to the 1 week therapy with oral linezolid suspension 20 $\mathrm{mg} / \mathrm{kg} /$ day, $1 \mathrm{ml} / \mathrm{t}$.d.s. No VRE was isolated from baby on a repeat stool culture 1 week after the linezolid therapy. He was discharged with the advice for the continuance of linezolid for seven more days.

Conclusion: Isolation of MDR-VRE from the blood culture of the baby and stool specimens of the mother and the baby with the same antibiogram profile and clonal similarities reveals that maternal gut colonization was responsible for neonatal sepsis. Optimal infection control measures and the development of guidelines for monitoring VRE colonization in pregnant women might be useful in reducing the occurrence of neonatal sepsis.
\end{abstract}

Keywords: VRE, Neonatal Sepsis, Gut colonization

\section{Background}

Enterococci, regarded as harmless intestinal commensals of little clinical significance, over the past few decades have evolved as an important nosocomial pathogen [1]. This was mainly attributed to its acquisition of resistance to multiple antibiotics [2]. Vancomycin-resistant enterococcal infections in the neonatal ICUs are growing global problems. Neonatal infections due to Vancomycin-Resistant Enterococcus (VRE) could be by way of vertical transmission from the mother's gastrointestinal tract or skin or vaginal canal or even could be acquired horizontally as cross-infection from the

\footnotetext{
*Correspondence: supram.gowda@gmail.com

'Department of Medical Microbiology, Manipal College of Medical Sciences, Pokhara, Nepal

Full list of author information is available at the end of the article
}

hospital environment [3, 4]. Whereas, early onset neonatal sepsis happens invariably due to pathogens acquired from the amnion or birth canal [4]; the origin of late-onset cases that occur beyond 7 days of age is less well established. Not much is known about the source for the transmission of this organism in causing infection in the neonates. Thus, we report a case of early onset neonatal septicemia by VRE, probably acquired from the mother.

\section{Case presentation}

A male newborn child was admitted to the neonatal intensive care unit (NICU) because of vomiting and nasal flaring, immediately after birth. The baby weighed $3.1 \mathrm{~kg}$ and was born by normal vaginal delivery to a 27 -year primigravida at 42 weeks of gestation. The Apgar scores

(c) The Author(s). 2019 Open Access This article is distributed under the terms of the Creative Commons Attribution 4.0 International License (http://creativecommons.org/licenses/by/4.0/), which permits unrestricted use, distribution, and reproduction in any medium, provided you give appropriate credit to the original author(s) and the source, provide a link to the Creative Commons license, and indicate if changes were made. The Creative Commons Public Domain Dedication waiver (http://creativecommons.org/publicdomain/zero/1.0/) applies to the data made available in this article, unless otherwise stated. 
were $7 / 10$ at $1 \mathrm{~min}$ and $8 / 10$ at $5 \mathrm{~min}$. The baby was meconium stained, with a heart rate of $172 / \mathrm{min}$, respiratory rate $74 / \mathrm{min}$, temperature $98.2^{\circ} \mathrm{F}$, and $\mathrm{SpO}_{2} 88 \%$. He was diagnosed to have early-onset neonatal sepsis. There was no history of antibiotic treatment, vaginal discharge or premature rupture of membrane or any maternal febrile episode during the antenatal period. The baby was shifted to NICU, and was empirically managed with IV (intravenous) ampicillin (100 mg/kg/dose, IV t.d.s), gentamicin $(5 \mathrm{mg} / \mathrm{kg} / \mathrm{per}$, IV o.d), oxygen inhalation and intravenous infusion of dextrose saline.

The baby's white blood cells count was $14,500 / \mathrm{mm}^{3}$ with $83 \%$ neutrophils, $17 \%$ lymphocytes. His hemoglobin was $15.2 \mathrm{~g} / \mathrm{dl}$; platelet count was $250,000 / \mathrm{mm}^{3}$. Blood biochemistry revealed $\mathrm{Na}^{+} 143 \mathrm{meq} / \mathrm{L}, \mathrm{K}^{+} 4.6 \mathrm{meq} / \mathrm{L}$, urea $18 \mathrm{mg} / \mathrm{dl}$, creatinine $0.6 \mathrm{mg} / \mathrm{dl}$ and $\mathrm{Ca}^{++} 9.6 \mathrm{~g} / \mathrm{dl}$. CRP was $48 \mathrm{mg} / \mathrm{L}$. Neonate's blood sent for culture on day 1 of admission, grew Enterococcus faecium identified by conventional techniques [5]. Antibiotic susceptibility as determined by the Kirby-Bauer disc diffusion method [6] revealed the isolate to be resistant to penicillin (10 units), erythromycin $(15 \mu \mathrm{g})$, gentamicin $(10 \mu \mathrm{g})$, ciprofloxacin $(5 \mu \mathrm{g})$, vancomycin $(30 \mu \mathrm{g})$ and teicoplanin $(30 \mu \mathrm{g})$, but susceptible to linezolid $(30 \mu \mathrm{g})$ and chloramphenicol $(30 \mu \mathrm{g})$. The isolate possessed high-level resistance to vancomycin, $(\mathrm{MIC}=128 \mu \mathrm{g} / \mathrm{ml})$ and teicoplanin $(\geq 256 \mu \mathrm{g} / \mathrm{ml})$ as tested by $\mathrm{E}$ test. On day 3, he had an episode of seizure which was managed with intravenous phenytoin $20 \mathrm{mg} / \mathrm{kg}$ stat, followed by a maintenance dose of $5 \mathrm{mg} / \mathrm{kg} /$ day b.d until convulsions were controlled. Thereafter, he was stabilized on phenobarbitone ( $5 \mathrm{mg} / \mathrm{kg} /$ day/o.d).

Based upon the above, the case was diagnosed as mild meconium aspiration syndrome with early-onset neonatal VRE septicemia. The antibiotic therapy was switched over to suspension linezolid $20 \mathrm{mg} / \mathrm{kg} /$ day, 1 $\mathrm{ml} / \mathrm{t}$.d.s $(100 \mathrm{mg} / 5 \mathrm{ml})$ orally in view of the antibiotic susceptibility report.

VRE was not isolated from the environment of NICU during this period by microbiology surveillance. Surveillance was conducted by collecting samples from different sites of the NICU either in direct or indirect contact with the baby. These were feeding tubes, oxygen masks, linen and beddings, door handles, wash basins and, personal belongings such as the stethoscope and mobile phones of attending doctors and nurses, and hands of all health-care personnel.

For estimating gut colonization of both the baby and the mother and maternal vaginal colonization, we performed stool cultures (semi-quantitative) of both and vaginal swab culture of the mother. Stool specimens of the mother and the baby yielded heavy growth of Vancomycin-Resistant Enterococcus faecium with similar antibiogram profile. The antibiotic sensitivity patterns of the stool isolates were exactly similar to the isolate from the neonatal blood. No VRE was isolated from a maternal high vaginal swab. All the three isolates (both isolates from the stool and one from the neonatal blood) harbored $v a n \mathrm{~A}$ gene as detected by polymerase chain reaction (PCR) assay [7] (Additional file 1: Figure S1). Typing of the isolates was done by pulsed-field gel electrophoresis (PFGE) as previously described [8] including one characterized clinical isolate and results were inspected visually. The PFGE pattern of all three isolates confirmed these to be clonally related (Additional file 1: Figure S1). The limitation of the PFGE analysis was that the results were not confirmed by digesting with a secondary enzyme. No VRE was isolated from baby on a repeat stool culture 1 week after the linezolid therapy. He was discharged with the advice for the continuance of linezolid for seven more days. At the time of discharge, all vital functions of the baby were within normal limits.

\section{Discussion}

Of all the species of Enterococci, E faecalis and E faecium are the commonest human pathogens. Serious enterococcal infections are often difficult to treat because the organism exhibits intrinsic resistance to various antibiotics including penicillins, cephalosporins, and sometimes to aminoglycosides and clindamycin and other lincosamides [3]. The recent emergence of multidrug-resistant (MDR) Enterococci, especially VRE has provoked the occurrence of several nosocomial outbreaks worldwide [9].

Enterococci are among the first few bacteria that colonize the neonatal gastrointestinal tract from mother's vaginal and gastrointestinal flora during delivery, or via ingestion of breast milk or through close association with the mother [10]. Although, we did not try to explore the exact route of transmission of the organism in the present case, the two possible routes of spread [11-13], in our view, may be (i) from maternal gut to maternal bloodstream, then transplacentally to the fetus, or (ii) maternal gut to neonatal oral cavity during parturition, spreading from there to neonatal blood. Since it is a case of early onset neonatal sepsis, the time frame suggests the first route be the most plausible one, although such pathways are not well documented among Enterococcus. Emphasizing further on this, isolating VRE from the neonate's blood, mother's and neonate's gut, with similar antibiogram and similar PFGE pattern supports the proposition of the mother is the source of infection.

Employing PCR ribotyping, Kaushal S and colleagues [14], from India reported vanA genotypes of E faecalis in the stool and blood of a neonate with septicemia and stated that gastrointestinal carriage could be the possible source of sepsis. Carl MA, et al. [15] suggested that vertically transmitted gram negative bacilli (GNB) and 
Group B Streptococci during vaginal delivery, colonize the neonatal gastrointestinal tract with the subsequent episode of late-onset septicemia. Das et al. [16], noticed that neonates with GNB in the gut had a consistently higher incidence of clinical sepsis than those without such colonization.

Our observation of similar PFGE patterns of the fecal and blood isolates substantiates strong association of maternal gut colonization with neonatal sepsis. The baby in the present case was diagnosed as mild meconium aspiration syndrome on clinical grounds. Bacterial diversity of meconium was assessed previously in preterm and term babies which had a profound effect on the health of the newborn, more so of the preterm babies [17]. We did not check meconium for sterility. Moles L, et al. [17] and Jiménez E et al. [18] proposed that fetal gut might not be sterile and that a part of the bacterial flora found in the meconium might not be of postnatal origin all the time. Besides, it was also postulated that many of the bacterial genera found in the meconium, including Enterococcus were common inhabitants of the maternal gut [19]. Transplacental migration of $E$ faecium was demonstrated by Jiménez E et al. [18] in an experiment where the pregnant mice were fed with milk containing labeled E faecium. The meconium from the pups delivered by cesarean section yielded same labeled E faecium. The gut flora of the mother can spread to the neonate during the surgical procedure [20, 21], via trachea [22] and can lead to bacteremia.

Nevertheless, it is needless to emphasize that nosocomial sepsis following gut colonization in the neonates is of paramount clinical relevance, especially in developing countries, where inappropriate infection control measures prevail in most of the hospitals. The pathogen $E n$ terococcus in the present case was resistant to multiple antibiotics including vancomycin and teicoplanin. In the face of increasing resistance rates and limited treatment options, prevention of multidrug-resistant Enterococcus infections is of utmost importance. Thus CDC recently recommended the use of all contact precautions like barrier nursing, hand washing etc. not only for carriers of MDR Enterococcus but for all MDR organisms in order to prevent the spread of these organisms in health care settings [23]. Some hospitals practiced routine screening and decolonization of MRSA carriers to prevent the subsequent spread of infections [24]. Contrast to this effective screening and decolonization of VRE carriers are not practiced in many hospitals as VRE is much less common invasive pathogens than MRSA and tends to impact a smaller subset of patients [25].

Notwithstanding the above, other researchers $[3,4,14]$ too, reported high vanA VRE carriage rate in the feces of patients admitted to ICUs. The predominance of vanA genotype of Enterococcus faecium was previously documented in Asian countries such as Japan, Korea, China, and India [3, 9]. Enterococcus belonging to the vanA type has become a cause of concern because of its high-level resistance to vancomycin, and high potential of transfer of this gene to other potent pathogens like Staphylococcus aureus [26].

\section{Conclusion}

Isolation of MDR-VRE from stool specimens of both the mother and the baby with similar antibiogram and PFGE pattern reveals that maternal gut colonization might be responsible for neonatal sepsis. There is a need for implementation of strategies to prevent the dissemination of these pathogens from mother to neonate and among the newborn babies. Optimal infection control measures and the development of guidelines for the control of colonization by VRE in pregnant women might be useful in the reduction of neonatal sepsis.

\section{Additional file}

Additional file 1: Figure S1. (a) Polymerase chain reaction amplification of vanA gene in Enterococcus fecacieum isolated from baby blood (lane D) and stool of the neonate (lane E) and mother (lane F). (Lane A: 100 bp ladder, B: positive control for vanA gene (732 bp), C: negative control). (b) Typing of the isolates: Strain relation according to PFGE (Lane 1: molecular marker) (PCR 20 bp Low Ladder, Sigma-Aldrich, USA). PFGE showed that both blood and stool isolates were pulso type A. (PNG $2020 \mathrm{~kb}$ )

\section{Abbreviations}

CRP: C-reactive protein; IV: Intravenous; MDR: Multi Drug Resistant; NICU: Neonatal intensive care unit; PCR: Polymerase chain reaction; SPO2: Peripheral capillary oxygen saturation; t.d.s: Thrice a day; VRE: Vancomycin Resistant Enterococci

\section{Acknowledgements}

The authors thank the patient and his family for their cooperation throughout the study and consent to this paper. We extend our special thanks to Manipal Teaching Hospital, Pokhara, Nepal, for providing the facility to carry out the study.

\section{Funding}

The authors have not received any funding from any agency to support the work presented in this submission.

\section{Availability of data and materials}

Not applicable.

\section{Authors' contributions}

SHS: observed the incidence and case, performed the laboratory studies, molecular analysis, literature review and wrote the manuscript; DC: observed the incidence and case, collected specimens, case follow-up, treatment. RA and SP: Identification of isolates, molecular studies and manuscript writing. SG: providing clinical relevance and manuscript editing. NN, IB: Contributed toward manuscript writing, and critically reviewed the manuscript. All authors read and approved the final manuscript.

\section{Ethics approval and consent to participate}

Written informed consent for this case report was obtained from the patient mother in the study. Ethical approval was not required by our Institution, necessary permission was taken for publication from Intuitional Scientific review committee of Manipal College of Medical Sciences, Pokhara, Nepal. 


\section{Consent for publication}

Written informed consent for the publication of this case report was obtained from infant's mother.

\section{Competing interests}

The authors declare that they have no competing interests.

\section{Publisher's Note}

Springer Nature remains neutral with regard to jurisdictional claims in published maps and institutional affiliations.

\section{Author details}

'Department of Medical Microbiology, Manipal College of Medical Sciences, Pokhara, Nepal. ${ }^{2}$ Melaka Manipal Medical College, Manipal, India. ${ }^{3}$ Jawaharlal Institute of Postgraduate Medical Education \& Research, Puducherry, India.

\section{Received: 2 October 2018 Accepted: 3 February 2019}

Published online: 08 February 2019

\section{References}

1. Emori TG, Gaynes RP. An overview of nosocomial infections, including the role of the microbiology laboratory. Clin Microbiol Rev. 1993;6(4):428-42.

2. Murray BE. The life and times of the Enterococcus. Clin Microbiol Rev. 1990; 3(1):46-65.

3. Shantala GB, Nagarathnamma T, Pooja DR. et.alNeonatal septicaemia caused by vancomycin resistant enterococcus faecium-a case report. J Clin Diagn Res. 2014;8(11):DD03-4. https://doi.org/10.7860/JCDR/2014/10284.5220.

4. Choudhry O, Gathwala G, Singh J. Vancomycin resistant enterococci in neonatal ICU- a rising menace. Indian J Pediatr. 2010;77:1446-7. https://doi. org/10.1007/s12098-010-0243-6.

5. Mackie TJ, McCartney JE. Practical medical microbiology. 14th ed. New York: Churchill Livingstone; 1996.

6. Clinical and Laboratory Standard Institute. Performance Standard for Antimicrobial Susceptibility Testing: $23^{\text {rd }}$ Informational Supplement, M100S23. Wayne: Clinical and Laboratory Standard Institute; 2013.

7. Dutka-Malen S, Evers S, Courvalin P. Detection of glycopeptide resistance genotypes and identification to the species level of clinically relevant enterococci by PCR. J Clin Microbiol. 1995;33:1434.

8. Gozalan A, Coskun-Ari FF, Ozdem B, et al. Molecular characterization of vancomycin-resistant Enterococcus faecium strains isolated from carriage and clinical samples in a tertiary hospital, Turkey. J Med Microbiol. 2015; 64(7):759-66. https://doi.org/10.1099/jmm.0.000088.

9. Banerjee T, Anupurba S, Filgona J, Singh DK. Vancomycin-resistance enterococcal colonization in hospitalized patients in relation to antibiotic usage in a tertiary care hospital of North India. J Lab Physicians. 2015;7:108-11.

10. Sharma M, Yadav A, Yadav S. Enterococcal neonatal Septicaemia. Int J Pharm Bio Sci. 2012:3(3:(B)):781-6.

11. Arora N, Sadovsky Y, Dermody TS, Coyne CB. Microbial vertical transmission during human pregnancy. Cell Host Microbe. 2017;21(5):561-7. https://doi. org/10.1016/j.chom.2017.04.007

12. Berg RD. Bacterial translocation from the gastrointestinal tract. Trends Microbiol. 1995;3:149-54

13. MacFie J, O'Boyle C, Mitchell Cea. Gut origin of sepsis: a prospective study investigating associations between bacterial translocation, gastric microflora, and septic morbidity. Gut. 1999:45:223-8.

14. Kaushal S, Banerjee T, Anupurba S, Kumar A. Vancomycin-resistant enterococci in neonatal stool as a cause of septicemia: challenges for infection control practices. Indian J Pathol Microbiol. 2016:59:548-50.

15. Carl MA, Ndao IM, Springman AC, et al. Sepsis from the gut: the enteric habitat of bacteria that cause late-onset neonatal bloodstream infections. Clin Infect Dis. 2014;58(9):1211-8. https://doi.org/10.1093/cid/ciu084 Epub 2014 Mar 18

16. Das $P$, Singh AK, Pal T, et al. Colonization of the gut with gram-negative bacilli, its association with neonatal sepsis and its clinical relevance in a developing country. J Med Microbiol. 2011;60(Pt 11):1651-60. https://doi. org/10.1099/jmm.0.033803-0 Epub 2011 Jun 30.

17. Moles L, Gómez M, Heilig H, Bustos G, Fuentes S, de Vos W, et al. Bacterial diversity in meconium of preterm neonates and evolution of their fecal microbiota during the first month of life. PLoS One. 2013:8(6):e66986 https://doi.org/10.1371/journal.pone.0066986.
18. Jiménez E, Marín ML, Martín R, Odriozola JM, Olivares $M$, et al. Is meconium from healthy newborns actually sterile? Res Microbiol. 2008;159:187-93.

19. Gosalbes MJ, Llop S, Valles Y, Moya A, Ballester F, et al. Meconium microbiota types dominated by lactic acid or enteric bacteria are differentially associated with maternal eczema and respiratory problems in infants. Clin Exp Allergy. 2013:43:198-211.

20. Donnell SC, Taylor N, van Saene HK, et al. Infection rates in surgical neonates and infants receiving parenteral nutrition: a five-year prospective study. J Hosp Infect. 2002;52:273-80.

21. MacFie J. Current status of bacterial translocation as a cause of surgical sepsis. Br Med Bull. 2004;71:1-11.

22. Schwartz SN, Dowling JN, Benkovic C, DeQuittner-Buchanan M, Prostko T, Yee RB. Sources of gram-negative bacilli colonizing the tracheae of intubated patients. J Infect Dis. 1978;138:227-31.

23. Siegel JD, Rhinehart $\mathrm{E}$, Jackson $\mathrm{M}$, et al. Healthcare Infection Control Practices Advisory Committee. Management of multidrug-resistant organisms in health care settings, 2006. Am J Infect Control. 2007;35(10 Suppl 2):S165-93

24. Robiscek J, Beaumont JL, Paule SM, et al. Universal surveillance for MRSA in 3 affiliated hospitals. Ann Intern Med. 2008:148:409-18.

25. Hidron Al, Edwards JR, Patel J, et al. NHSN annual update: antimicrobialresistant pathogens associated with healthcare-associated infections: annual summary of data reported to the National Healthcare Safety Network at the Centers for Disease Control and Prevention, 2006-2007. Infect Control Hosp Epidemiol. 2008;29:996-1011.

26. de Niederhäusern S, Bondi M, Messi P, Iseppi R, Sabia C, Manicardi G, Anacarso I. Vancomycin-resistance transferability from VanA enterococci to Staphylococcus aureus. Curr Microbiol. 2011;62(5):1363-7. https://doi.org/10. 1007/s00284-011-9868-6.

\section{Ready to submit your research? Choose BMC and benefit from:}

- fast, convenient online submission

- thorough peer review by experienced researchers in your field

- rapid publication on acceptance

- support for research data, including large and complex data types

- gold Open Access which fosters wider collaboration and increased citations

- maximum visibility for your research: over $100 \mathrm{M}$ website views per year

At BMC, research is always in progress.

Learn more biomedcentral.com/submissions 